\title{
THE CIVIL WAR
}

The Civil War is a poem which Abraham Cowley (1618-67) did not complete, for political and historical reasons, and of which only the first volume was published; the other two volumes have been considered irrecoverably lost since Cowley's death. Professor Pritchard recently found two copies of the complete poem in a collection of family papers at the Hertfordshire County Record Office and here presents a corrected edition of the first and previously published book, and the text of the hitherto unpublished books two and three.

The poem is a major addition to the body of Cowley's poetry; it has close and sometimes surprising connections with much of his other work. It is not only the most extended and important of his political poems but a significant addition to the genre of the political poem. It is also unique as the attempt by a poet of stature to give epic treatment to the events of the English Civil War.

Professor Pritchard provides a discussion of the personal, historical, and literary contexts of the poem in the introduction, as well as of textual problems and methods, showing the way in which the poem is shaped both by contemporary history and polemics and by classical and later literary tradition.

ALlan D. PRITChard is Professor in the Department of English, University College, University of Toronto. 
To whole cunst Zeate ye Caledoncing owe Thair fomer Mliceries and Retellions now. Can yow alas the pover from Iyrants take? Why God simselfe yow y worts Torant make.

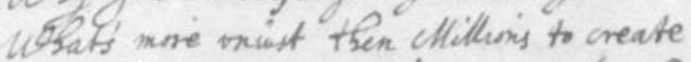
For endlefre paings and dame men for their Fate. the ginnes well by arew now on God are thewne, youle find at a great Iriall all ayour none

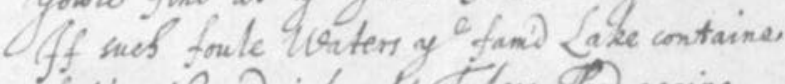
Cets ratier Drinke ole tybers 600 againe. Tet ow preat Thames pay Flomage os before, Rather then ncw and coorser streand adone. If wer're resolod and fuxt our wany to loose

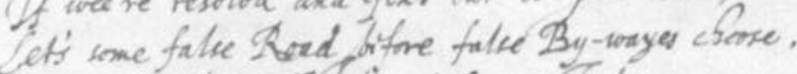
But mather let ow dis ye Oceans Jy de As from $y^{e}$ lleold from yo worlds Favls divide. Let other lands love darknes: this ow Right. ow $r$ Countries Priveledge to save lest of C Vigst. The frdependents thair two thersent sents. Who nito Rays yc seamelesic Vrsture rent. In whose pormo Churcles may at once bee secre Hore Pooes then kare at Ronce ince Piter binine. Ted dimell Fleciesy of vild ctlaneers crew

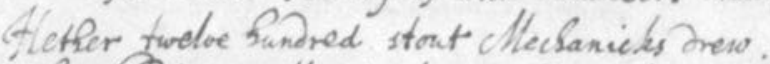
There Snitian clloniters! Wretches yt begit Oonfusion fere, and mast interit it. atsings All (they fold) to all must Common bee. Are thaise they who defend ou Prypertic?

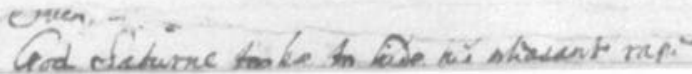


ABRAHAM COWLEY

\section{The Civil War}

EDITED BY ALLAN PRITCHARD 


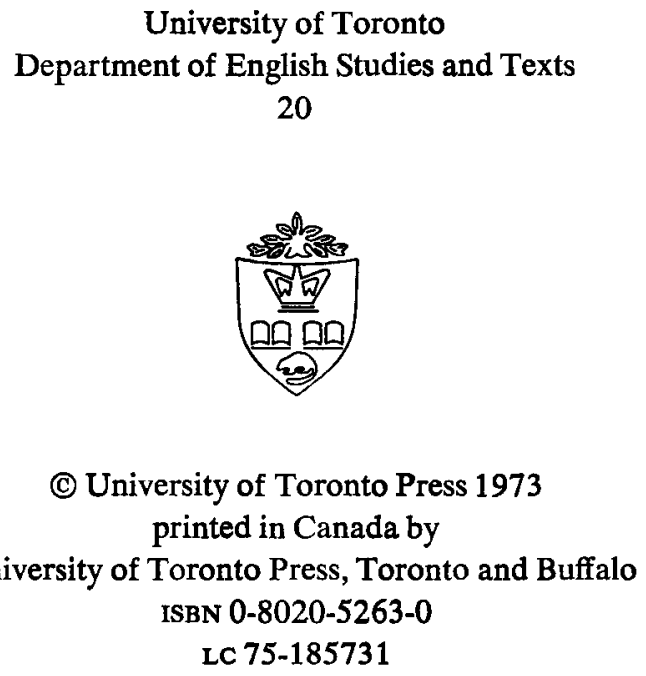

